Abstracta Iranica Abstracta Iranica

Revue bibliographique pour le domaine irano-aryen

Volume 24 | 2003

Comptes rendus des publications de 2001

\title{
Bīst sāl bā Keleydar. Našr-e Kūčak, 1380/2001, 424 p. [Vingt ans avec Keleydar]
}

\section{Christophe Balaÿ}

\section{(2) OpenEdition}

1 Journals

\section{Édition électronique}

URL : http://journals.openedition.org/abstractairanica/34848

DOI : 10.4000/abstractairanica.34848

ISSN : 1961-960X

Éditeur :

CNRS (UMR 7528 Mondes iraniens et indiens), Éditions de l'IFRI

Édition imprimée

Date de publication : 15 mai 2003

ISSN : 0240-8910

Référence électronique

Christophe Balaÿ, «Bīst sāl bā Keleydar. Našr-e Kūčak, 1380/2001, 424 p. [Vingt ans avec Keleydar] », Abstracta Iranica [En ligne], Volume 24 | 2003, document 301, mis en ligne le 05 janvier 2010, consulté le 25 septembre 2020. URL : http://journals.openedition.org/abstractairanica/34848 ; DOI : https:// doi.org/10.4000/abstractairanica.34848

Ce document a été généré automatiquement le 25 septembre 2020.

Tous droits réservés 


\title{
Bīst sāl bā Keleydar. Našr-e Kūčak, 1380/2001, 424 p. [Vingt ans avec Keleydar]
}

\author{
Christophe Balaÿ
}

1 Le roman Keleydar de Maḥmūd Dowlatābādī a été sans discussion un des événements littéraires des premières années de la révolution et il fut sans aucun doute un des romans les plus lus et les plus discutés de ces vingt dernières années, aussi admiré que détesté, en tout cas un des plus populaires, probablement parce qu'il porte un regard moderne et qu'il donne une voix contemporaine à une société traditionnelle, voire tribale, en voie de disparition; à une société dont la révolution a révélé le caractère encore archaïque. Le roman fleuve qu'est Keleydar exhale ce parfum de nostalgie puissamment attractif. Le nombre et la diversité des points de vue ici rassemblés sont un écho de cette œuvre dans l'opinion publique et la critique. On trouvera 33 articles dont un de Dowlatābādī lui-même, datés de 1979 à 2000. Vingt ans de critique qui démontrent la constance de l'intérêt porté à ce roman. Bien sûr, comme l'auteur l'avoue dans la préface, cette collection n'est pas exhaustive et, en effet, on soupçonne quelque peu l'éditeur scientifique d'avoir écarté non seulement ceux qu'il annonce mais d'autres encore pour leurs analyses plutôt négatives de ce roman. En tout état de cause, on a déjà là un bel aperçu de la réception de ce grand texte. Chaque article est soigneusement référencé (titre de l'ouvrage, ou numéro de la revue et date).

\section{INDEX}

Thèmes : 11.1.2. Littérature persane moderne 
AUTEURS

CHRISTOPHE BALÄ̈

IFRI/INALCO - Téhéran/Paris 